\title{
Expression of matrix metalloproteinase 2 and 9 in breast cancer and breast fibroadenoma: a randomized, double-blind study
}

\author{
Luana Mota Martins', Carla Solange de Melo Escorcio Dourado', Larysse Maira \\ Campos-Verdes ${ }^{1}$, Fabiane Araújo Sampaio', Camila Maria Simplício \\ Revoredo', Danylo Rafhael Costa-Silva', Maria da Conceição Barros- \\ Oliveira', Elmo de Jesus Nery Junior', Lucia Maria do Rego- \\ Medeiros², Luiz Henrique Gebrim', Francisco Adelton Alves-Ribeiro', Gilmara \\ Péres Rodrigues', Diego Cipriano Chagas ${ }^{1}$, Dilina do Nascimento Marreiro ${ }^{1}$ \\ and Benedito Borges da Silva ${ }^{1,2}$ \\ ${ }^{1}$ Postgraduate Program, Northeast Biotechnology Network (RENORBIO), Biotechnology in Health, Federal University of Piaui, \\ Teresina, Piaui 64000-020, Brazil \\ ${ }^{2}$ Facid / Wyden Differential Integral Medicine Faculty, Department of Mastology, Teresina, Piaui 64052-810, Brazill \\ Correspondence to: Benedito Borges da Silva, email: beneditoborges@globo.com \\ Keywords: breast neoplasms; fibroadenoma; matrix metalloproteinase-2; matrix metalloproteinase-9; immunohistochemistry \\ Received: September 17, $2019 \quad$ Accepted: November 06, $2019 \quad$ Published: December 03, 2019 \\ Copyright: Martins et al. This is an open-access article distributed under the terms of the Creative Commons Attribution License \\ 3.0 (CC BY 3.0), which permits unrestricted use, distribution, and reproduction in any medium, provided the original author and \\ source are credited.
}

\section{ABSTRACT}

Background: Matrix metalloproteinases (MMPs) 2 and 9 may play an important role in cell proliferation and dissemination of cancer. However, few studies have compared the expression of these proteins between breast cancer and fibroadenoma.

Material and methods: A randomized, double-blind study was carried out in $\mathbf{6 6}$ premenopausal women, aged 20-49 years, who had been diagnosed with fibroadenoma or breast cancer. The patients were divided into two groups: Group A, control (fibroadenoma, $n=36$ ) and Group $B$, study (cancer, $n=30$ ). Immunohistochemical analysis was performed using tissue samples of fibroadenoma and breast cancer to assess MMP-2 and MMP-9 antigen expression. Cells were considered positive if exhibiting brown cytoplasmic staining. Fisher's exact test was used to compare the percentage of cases with cells expressing MMP-2 and MMP-9 in control and study groups $(p<0.05)$.

Results: Light microscopy showed a higher concentration of cells with positive cytoplasmic staining for MMP-2 and MMP-9 expression in breast cancer than in fibroadenoma. The percentage of cases with cells expressing MMP-2 in the control and study groups was $41.67 \%$ and $86.11 \%$, respectively $(p<0.0009)$, whereas the percentage of cases with cells expressing MMP-9 in groups A and B was $66.67 \%$ and $93.33 \%$, respectively $(p<0.0138)$. MMP-2 and MMP-9 positive expression was significantly higher in moderately differentiated tumors compared to well and poorly differentiated tumors, $\mathrm{p}<0.005$ and $\mathrm{p}<0.001$, respectively.

Conclusions: The current study shows that MMP-2 and MMP-9 protein expression was significantly higher in the breast cancer than in the fibroadenoma and also in moderately differentiated breast cancer. 


\section{INTRODUCTION}

Breast cancer is the most common malignancy that affects women worldwide [1]. This disease is the second most frequently found cancer in the female population of Brazil, and 59,700 new cases and 14,206 deaths have been estimated in the year 2018 [2]. Although early detection and targeted therapy of breast cancer have improved disease prognosis [3], it has been suggested that more adequate therapeutic and prognostic strategies for breast cancer can be formulated with the use of protein biomarkers such as cell proliferation and apoptosis, since they have the advantage of suffering modifications before any clinical response of the tumor to treatment and may suggest changes in the therapy [4-6]. Biomarkers as matrix metalloproteinases, a family of zinc-dependent endopeptidases, whose major members of the family are MMP-2 and MMP-9 have been related to the pathogenesis of breast cancer $[7,8]$.

These proteinases have aroused the interest of researchers due to their association with cell proliferation, capacity to degrade collagen IV found primarily in the basal lamina, and thus favoring the migration of malignant cells. Furthermore, metalloproteinases are correlated with angiogenesis, which is essential for tumor growth and formation of metastases [9-11]. Studies have showed that concentrations of MMP-2 and MMP-9 are increased in women with breast cancer, and are associated with an unfavorable prognosis [12-14]. In addition, the literature has shown increased expression of MMP-2 and -9 in breast cancer in women with lymph node metastasis as compared to the expression of these gelatinases in breast cancer without metastases in axillary lymph nodes [15-18].

According to Ciurea et al. [19], fibroadenomas are the most common benign lesions in young women of reproductive age and some authors do not consider fibroadenoma as a tumor, preferring to label it as an aberration of normal development and involution (ANDI) [20]. Likewise, this consideration of the fibroadenoma as an alteration of normal breast tissue allows the use of samples from this tumor as control group for evaluating the expression of biomarkers in breast cancer such as metalloproteinases. Therefore, the prevalence of fibroadenoma of the breast and breast cancer in reproductive-aged women, the role of matrix metalloproteinase as a potential marker of tumor development and aggressiveness, in addition to the paucity of studies evaluating MMP expression in fibroadenoma and breast cancer, motivated us to create the design of current study.

\section{RESULTS}

Light microscopy showed greater concentration of stained cytoplasm for MMP-2 and MMP-9 in breast cancer in comparison to fibroadenoma (Figure 1). The characteristics of both groups were similar, except for age and waist circumference (Table 1). Concerning quantification of immunohistochemical antigen expression, the percentage of positive cases for MMP2 in group A (fibroadenoma) and B (breast cancer) was $15(41.67 \%)$ and $25(86.11 \%)$, respectively $(\mathrm{p}<0.0009)$, while the percentage of positive cases for MMP-9 in breast tumor tissues of women from groups A and B was $25(66.67 \%)$ and $28(93.33 \%)$, respectively $(\mathrm{p}<0.0138)$ (Table 2). Regarding the histological grade, the breast cancer group showed positive expression for MMP-2 in $13(52 \%)$ moderately differentiated (histological grade II) tumors, $10(40 \%)$ histological grade III tumors and $2(8 \%)$ histological grade I tumors. MMP-2 positive expression was significantly higher in moderately differentiated tumors compared to well and poorly differentiated tumors $(\mathrm{p}<0.005)$. MMP-9 expression was positive in $14(50 \%)$ histological grade II tumors, 12 (43\%) histological grade III tumors and $2(7 \%)$ histological grade I tumors and was significantly higher in histological grade II than Grade I and III $(\mathrm{p}<0.001)$.

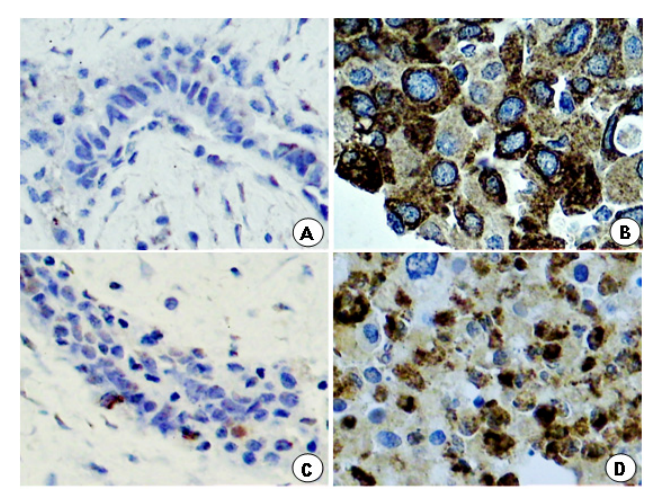

Figure 1: Photomicrography of histological section of a portion of fibroadenoma and breast cancer, showing: (B, D) innumerous cells with strong brown-stained cytoplasm for MMP-2 and MMP-9 in the breast cancer group compared to sparse brown stained cytoplasm in the breast fibroadenoma group (A, C). 
Table 1: Characteristics of the patients

\begin{tabular}{lccc}
\hline & $\begin{array}{c}\text { Group A (Fibroadenoma) } \\
(\mathbf{n}=\mathbf{3 6}) \text { Mean } \pm \text { SD }\end{array}$ & $\begin{array}{c}\text { Group B (Breast Cancer) } \\
(\mathbf{n}=\mathbf{3 0}) \text { Mean } \pm \text { SD }\end{array}$ & p \\
\hline Age (years) & $32.92 \pm 9.46$ & $40.37 \pm 6.77^{*}$ & 0.0011 \\
Menarche age (yrs) & $12.86 \pm 1.16$ & $13.67 \pm 1.79$ & 0.0820 \\
BMI $\left(\mathrm{kg} / \mathrm{m}^{2}\right)$ & $24.23 \pm 4.79$ & $25.83 \pm 3.65$ & 0.1342 \\
WC $(\mathrm{cm})$ & $79.40 \pm 12.34$ & $83.92 \pm 8.92^{*}$ & 0.0480 \\
\hline
\end{tabular}

* There was a statistically significant differences between control and study groups $(\mathrm{p}<0.05)$.

\section{DISCUSSION}

Matrix metalloproteinases have increased proteolytic activity against the basement membrane, leading to propagation of malignant cells [21]. The present study evaluated MMP-2 and MMP-9 expression in breast cancer cells in comparison to breast fibroadenoma, considered by some authors as only an aberration of normal development and involution (ANDI) [20] and showed heterogeneity between the age of breast cancer patients and age of women with fibroadenoma. However, fibroadenoma is more common in younger women, while breast carcinoma is more frequently found in older women [22]. Waist circumference was larger in breast cancer patients which agrees with findings in literature, where some authors believe that premenopausal women with excessive visceral fat are at increased risk of developing triple-negative breast cancer, a more aggressive tumor [23].

The current study showed a higher concentration of cells with strong brown cytoplasmic staining for MMP-2 and MMP-9 in breast cancer cells than in fibroadenoma. Matrix metalloproteinases expression has been shown in both breast normal tissue fibroadenoma and breast cancers [8], nevertheless, there is a scarcity of studies in the literature comparing the immunohistochemical expression of these gelatinases between breast cancer and fibroadenoma. To the best of our knowledge, only one study in the literature evaluated the immunohistochemical expression of MMP-2 in breast cancer and fibroadenoma and showed that a high expression of MMP-2 in breast ductal carcinoma in situ was an early incident in the genetic course of the breast cancer [24]. On the other hand, the majority of studies in literature have investigated serum concentrations of MMP-2 and MMP-9 and showed a higher concentration of these serum proteins in breast cancer patients than in women with fibroadenoma, corroborating data of immunohistochemical expression $[15,16,25]$.

MMP-2 and MMP-9 participate in both early and late processes of tumor progression [26]. It is noteworthy that MMP activity may be direct through tumor proliferation and metastatic dissemination by degradation of the extracellular matrix and basement membrane. MMP activity may also be indirect by promoting angiogenesis [27]. MMP-9 in particular, has a significant role in this process by activating vascular endothelial growth factor (VEGF), which is one of the major contributors to the formation of new vessels and tumor growth [28].

Huang et al. [15] evaluated the expression of MMP-2 and MMP-9 in breast cancer tissue and serum of women with cancer and those with benign breast tumors, showing that $72 \%$ and $76 \%$ of women with breast cancer had a positive expression for MMP-2 and MMP9 , respectively. The authors also demonstrated higher serum levels of these metalloproteinases in breast cancer patients when compared to women with benign tumors. Sullu et al.[12] and Min et al. [17], also analyzed the immunohistochemical expression of MMP-2 and MMP9 in invasive ductal carcinoma and identified a strong cytoplasmic staining for MMP-9 in $66 \%$ and $93.8 \%$ of cases, respectively.

Therefore, our results are in accordance with findings by Li et al. [7] and Min et al. [17] who showed a significantly higher expression of MMP-2 and MMP9 in breast cancer than in normal adjacent tissue and grade II cancers, respectively. This suggests that these metalloproteinases are potentially associated with tumor aggressiveness and may be a prognostic biomarker of breast cancer. To the best of our knowledge, there is scarcity of studies evaluating the immunohistochemical expression of MMP-2 and MMP-9 in breast cancer and breast fibroadenoma. Nevertheless, Sampaio et al. [29] recently showed significantly higher expression of metallotionein-1, a zinc-linked protein, in breast cancer than in fibroadenoma. Thus, due to the paucity of studies in the literature, further studies with a larger sample size are necessary to improve knowledge of the role of MMP2 and MMP-9 in the progression and prognosis of breast cancer.

\section{PATIENTS AND METHODS}

\section{Patients}

The study was approved by Review Board of the Federal University of Piaui (CAAE: 
Table 2: Percentage of cases with cells expressing MMP-2 and MMP-9 in the breast fibroadenoma (Group A, control) and in the breast cancer (Group B, study)

\begin{tabular}{ccccc}
\hline Variable & Groups & Positive n (\%) & Negative n (\%) & Total n (\%) \\
\hline \multirow{2}{*}{ MMP-2 } & Fibroadenoma & $15(41.67 \%)$ & $21(58,33 \%)$ & $36(100.00)$ \\
& Breast cancer & $25(86.11 \%)^{*}$ & $5(13.89 \%)$ & $30(100.00)$ \\
\multirow{2}{*}{ MMP-9 } & Fibroadenoma & $24(66.67 \%)$ & $12(33,33 \%)$ & $36(100.00)$ \\
& Breast cancer & $28(93.33 \%)^{*}$ & $2(6.67 \%)$ & $30(100.00)$ \\
\hline
\end{tabular}

* The difference of MMP-2 and MMP-9 expression in the breast cancer group was statistically higher in comparison to fibroadenoma, $\mathrm{p}<0.0009$ and $\mathrm{p}<0.0138$, respectively.

43447015.8.0000.5214) and all the patients signed an informed consent term prior to the beginning of the study. In addition, we confirm that all methods were performed in compliance with current Brazilian laws, in conformity with ethical standards of institutional and national research committees, following the 1964 Helsinki Declaration and its later amendments. Patients were recruited at the Mastology Clinic of the Getúlio Vargas Hospital, Federal University of Piauí, Brazil, from October 2014 to October 2016. The study included premenopausal patients with levels of follicle-stimulating hormone $(\mathrm{FSH})<30 \mathrm{mUI} / \mathrm{ml}$, fibroadenoma or carcinoma of the breast and no previous oncologic treatment.

\section{Study design}

A randomized, double-blind study was carried out, involving 75 premenopausal women with breast tumors. Nine patients were excluded due to technical problems that precluded analysis. Patients were divided into two groups, control group (fibroadenoma, $\mathrm{n}=36$ ) and study group (breast cancer, $\mathrm{n}=30$ ). All study participants underwent a specialized surgical procedure for histologic and immunohistochemical confirmation of the tumor. Malignant tumors were classified as poorly differentiated (Grade III), moderately differentiated (Grade II) and welldifferentiated (Grade I) with a low degree of malignancy.

\section{Immunohistochemistry of MMP-2 and MMP-9}

For immunohistochemical analysis, breast tissue fragments were fixed in buffered formalin, cut into $3-\mu \mathrm{m}$ thick sections, deparaffinized in xylol for 5 minutes, dehydrated in absolute ethanol, washed in buffered saline solution at $\mathrm{pH} 7.4$ for 5 minutes and then treated for 5 minutes with $3 \%$ hydrogen peroxide $\left(\mathrm{H}_{2} \mathrm{O}_{2}\right)$ in buffer to block endogenous peroxide.

For antigen retrieval, the slides were placed in racks containing $0.21 \%$ of citric acid $(\mathrm{pH} 6.0)$ and heated in a microwave oven at maximum power for 15 minutes. A buffered saline solution with phosphate containing Tween (PBS-Tween) was added to the slides after they were allowed to cool for 20 minutes. Tissue samples were incubated overnight at $4-8{ }^{\circ} \mathrm{C}$ with primary monoclonal antibody of the rat NCL-MMP2-507 and NCL-MMP9-439 (dilution of 1:50). The slides were washed with PBSTween, instilled with secondary reagent (anti-mouse BA 2000, Vector Laboratories, Burlingame, CA) and incubated for 30 minutes at room temperature. After washing once again with PBS-Tween, the slides were instilled with ABC Elite detection system (PK 6100, Vector Laboratories) and incubated for 45 minutes at room temperature.

Samples were once again washed with PBS-Tween, instilled with DAB (1.0 ml of EnVision FLEX DAB to one drop of chromogen) and incubated for 5 minutes. Finally, the slides were rinsed in distilled water, counterstained with hematoxylin, stained with ammoniacal silver solution, dehydrated with absolute ethanol, passed through Coplin jars containing xylol and mounted on Permount resin. Cells that expressed proteins MMP-2 and MMP-9 were identified by brown cytoplasmic staining.

\section{Quantitative method}

Quantification was performed by two observers blinded to patient identity who were also previously unaware of the cases. The procedure was performed using a light microscope (Eclipse E-400 optical microscope, Nikon, Tokyo, Japan) connected to a video camera (CHC-370 N digital camera, Samsung, Seoul, Korea), that captured and transmitted the image to a computer equipped with Image Lab software, version 2.3, developed by Softium Informatica (São Paulo, Brazil) for image analysis.

A semi-quantitative analysis of MMP-2 and MMP9 immunoreactivity was performed, according to criteria established by Van Slooten et al. [30]. The following parameters were taken into consideration: intensity of cell staining (I) and fraction of stained neoplastic cells (F). Staining intensity was graded as: 0 (negative), 1 (weakly stained), 2 (moderately stained) or 3 (strongly stained). The fraction of stained cells was classified as follows: I $(0-25 \%)$, II $(25-75 \%)$ or III $(75-100 \%)$. The final result was achieved by a combination of two parameters ( $\mathrm{I}$ and $\mathrm{F}$ ) ranging from 0 to 6 . Cases with a final score $\geq$ 3 were classified as positive for MMP-2 and MMP-9. In all cases, brown cytoplasmic staining was adopted as a pattern of positivity. 


\section{Statistical analysis}

Data were analyzed using SPSS statistical program for Windows 8.0. A comparison of age between both groups was analyzed by the Mann-Whitney nonparametric test [31], while Fisher's exact test was used to assess Body Mass Index (BMI) and Waist Circumference (WC). The percentage of cases expressing MMP-2 and MMP9 between both groups was analyzed by Fisher's exact test. The expression of MMP 2 and MMP 9 in histological grades of breast cancer was analyzed by Friedman test. The significance level was set at $p<0.05$ [32].

\section{Author contributions}

L.M.M. F.D., C.S.E.D., L.M.C.V. and F.A.S. designed the study, analyzed and interpreted the data and wrote the manuscript. L.L.M., B.B.S., C.M.S.R., D. R. C. S, E. J. N. J., L. M. R.M. acquired the data. L.H.G., F. A. A. R., G. P. R. and D.C. C. revised the manuscript for intellectual content. D.N.M. and B.B.S. contributed equally.

\section{ACKNOWLEDGMENTS}

The authors are thankful for all the patients who participated in the current study and are grateful to the Postgraduate Program of the Federal University of Piauí, in Brazil.

\section{CONFLICTS OF INTEREST}

The authors have no conflict of interest.

\section{FUNDING}

No funding.

\section{Ethical approval}

The Internal Review Board of the Federal University of Piauí approved this protocol and all procedures in this study were in compliance with current Brazilian laws, following the 1964 Helsinki Declaration and its later amendments.

\section{REFERENCES}

1. Ferlay J, Soerjomataram I, Dikshit R, Eser S, Mathers C, Rebelo M, Parkin DM, Forman D, Bray F. Cancer incidence and mortality worldwide: sources, methods and major patterns in GLOBOCAN 2012. Int J Cancer. 2015; 136: E35986. https://doi.org/10.1002/ijc.29210. [PubMed]

2. Quintanilha LF, Souza LN, Sanches D, Demarco RS, Fukutani KF. The impact of cancer campaigns in Brazil: a
Google Trends analysis. Ecancermedicalscience. 2019; 13: 963. https://doi.org/10.3332/ecancer.2019.963. [PubMed]

3. Anderson KN, Schwab RB, Martinez ME. Reproductive risk factors and breast cancer subtypes: a review of the literature. Breast Cancer Res Treat. 2014; 144:1-10. http://doi.org/10;10.1007/s10549-014-2852-7. [PubMed]

4. Dowsett M, Smith IE, Ebbs SR, Dixon JM, Skene A, Griffith C, Boeddinghaus I, Salter J, Detre S, Hills M, Ashley S, Francis S, Walsh G, A'Hern R. Proliferation and apoptosis as markers of benefit in neoadjuvant endocrine therapy of breast cancer. Clin Cancer Res. 2006; 12: 1024s-30s http://doi.org/10.1158/1078-0432.CCR-05-2127. [PubMed]

5. Borges US, Costa-Silva DR, da Silva-Sampaio JP, EscórcioDourado CS, Conde AM Jr, Campelo V, Gebrim LH, da Silva BB, Lopes-Costa PV. A comparative study of Ki-67 antigen expression between luminal A and triple-negative subtypes of breast cancer. Med Oncol. 2017; 34: 156. http://doi.org/10.1007/s12032-017-1019-x. [PubMed]

6. Escórcio-Dourado CS, Martins LM, Simplício-Revoredo CM, Sampaio FA, Tavares CB, da Silva-Sampaio JP, Borges US, Alves-Ribeiro FA, Lopes-Costa PV, Lima-Dourado JC, da Silva BB. Bcl-2 antigen expression in luminal A and triple-negative breast cancer. Med Oncol. 2017; 34:161 http://doi.org/10.1007/s12032-017-1022-2. [PubMed]

7. Li H, Qiu Z, Li F, Wang C. The relationship between MMP-2 and MMP-9 expression levels with breast cancer incidence and prognosis. Oncol Lett. 2017; 14: 5865-70 http://doi.org/10.3892/ol.2017.6924.

8. Ren F, Tang R, Zhang X, Madushi WM, Luo D, Dang Y, Li Z, Wei K, Chen G. Overexpression of MMP Family Members Functions as Prognostic Biomarker for Breast Cancer Patients: A Systematic Review and Meta-Analysis. PLoS One. 2015; 10: e0135544.http://doi.org/10.1371/ journal.pone.0135544. [PubMed]

9. Amar S, Smith L, Fields GB. Matrix metalloproteinase collagenolysis in health and disease. Biochim Biophys Acta Mol Cell Res. 2017; 1864: 1940-51. http://doi. org/10.1016/j.bbamcr.2017.04.015. [PubMed]

10. Chen Y, Wang X, Chen G, Dong C, Zhang D. The impact of matrix metalloproteinase 2 on prognosis and clinicopathology of breast cancer patients: a systematic meta-analysis. PLoS One. 2015; 10: e0121404. http://doi. org/10.1371/jornal.pone.0121404. [PubMed]

11. Klein T, Bischoff R. Physiology and pathophysiology of matrix metalloproteases. Amino Acids. 2011; 41: 271-90. http://doi.org/10.1007/s00726-010-0689-x. [PubMed]

12. Sullu Y, Demirag GG, Yildirim A, Karagoz F, Kandemir B. Matrix metalloproteinase-2 (MMP-2) and MMP-9 expression in invasive ductal carcinoma of the breast. Pathol Res Pract. 2011; 207: 747-53. http://doi.org/10.1016/j. prp.09.010. [PubMed] 
13. Patel S, Sumitra G, Koner BC, Saxena A. Role of serum matrix metalloproteinase-2 and -9 to predict breast cancer progression. Clin Biochem. 2011; 44: 869-72. http://doi. org/10.1016/j.clinbiochem.2011.04.019. [PubMed]

14. Vasaturo F, Solai F, Malacrino C, Nardo T, Vincenzi B, Modesti M, Scarpa S. Plasma levels of matrix metalloproteinases 2 and 9 correlate with histological grade in breast cancer patients. Oncol Lett. 2013; 5: 316-20. http://doi.org/10.3892/ol.2012.977. [PubMed]

15. Huang J, Ang L, Liu MQ, Hu HG, Wang J, Zou Q, Zhao Y, Zheng L, Zhao M, Wu ZS. Serum and tissue expression of gelatinase and Twist in breast cancer. Eur Rev Med Pharmacol Sci. 2014; 18: 2662-69. [PubMed]

16. Jinga DC, Blidaru A, Condrea I, Ardeleanu C, Dragomir C, Szegli G, Stefanescu M, Matache C. MMP-9 and MMP-2 gelatinases and TIMP-1 and TIMP-2 inhibitors in breast cancer: correlations with prognostic factors. J Cell Mol Med. 2006; 10: 499-510. https://doi. org/10.1111/j.1582-4934.2006.tb00415.x. [PubMed]

17. Min KW, Kim DH, Do SI, Kim K, Lee HJ, Chae SW, Sohn JH, Pyo JS, Oh YH, Kim WS, Lee SY, Oh S, Choi SH, et al. Expression patterns of stromal MMP-2 and tumoural MMP-2 and -9 are significant prognostic factors in invasive ductal carcinoma of the breast. APMIS. 2014; 122: 1196206. http://doi.org/10.1111/apm.12285. [PubMed]

18. Zhao M, Hu HG, Huang J, Zou Q, Wang J, Liu MQ, Zhao Y, Li GZ, Xue S, Wu ZS. Expression and correlation of Twist and gelatinases in breast cancer. Exp Ther Med. 2013; 6: 97-100. https://doi.org/10.3892/etm.2013.1099. [PubMed]

19. Ciurea AI, Herţa HA, Iacoban CG, Fetica B, Rogojan L, Ciortea CA. Fibroadenomas and breast carcinoma: a possible answer to a frequently asked question. A pictorial essay. Med Ultrason. 2018; 20: 385-91. http://doi. org/10.11152/mu-1408. [PubMed]

20. Hughes LE, Mansel RE, Webster DJ. Aberrations of normal development and involution (ANDI): a new perspective on pathogenesis and nomenclature of benign breast disorders. Lancet. 1987; 2: 1316-19. http://doi.org/10.1016/ s0140-6736(87)91204-9.

21. Hadler-Olsen E, Fadnes B, Sylte I, Uhlin-Hansen L, Winberg JO. Regulation of matrix metalloproteinase activity in health and disease. FEBS J. 2011; 278: 28-45. http://doi. org/10.1111/j.1742-4658.2010.07920.X. [PubMed]

22. Sönmez K, Türkyilmaz Z, Karabulut R, Demiroğullari B, Ozen IO, Moralioğlu S, Başaklar AC, Kale N. Surgical breast lesions in adolescent patients and a review of the literature. Acta Chir Belg. 2006; 106: 400-04. https://doi. org/10.1080/00015458.2006.11679915. [PubMed]
23. Agresti R, Meneghini E, Baili P, Minicozzi P, Turco A, Cavallo I, Funaro F, Amash H, Berrino F, Tagliabue E, Sant M. Association of adiposity, dysmetabolisms, and inflammation with aggressive breast cancer subtypes: a cross-sectional study. Breast Cancer Res Treat. 2016; 157: 179-89. http://doi.org/10.1007/s10549-016-3802-3. [PubMed]

24. Peihong S, Perry F. Expression of nm23, MMP-2, TIMP-2 in breast neoplasm in Zhengzhou Center Hospital, China. Ethiop Med J. 2007; 45: 79-83. [PubMed]

25. Somiari SB, Somiari RI, Heckman CM, Olsen CH, Jordan RM, Russell SJ, Shriver CD. Circulating MMP2 and MMP9 in breast cancer - potential role in classification of patients into low risk, high risk, benign disease and breast cancer categories. Int J Cancer. 2006; 119: 1403-11. http://doi. org/10.1002/ijc.21989. [PubMed]

26. Ala-aho R, Kähäri VM. Collagenases in cancer. Biochimie. 2005; 87: 273-86. http://doi.org/10.1016/j. biochi.2004.12.009. [PubMed]

27. Hanemaaijer R, Verheijen JH, Maguire TM, Visser $\mathrm{H}$, Toet K, McDermott E, O'Higgins N, Duffy MJ. Increased gelatinase- $A$ and gelatinase- $B$ activities in malignant vs. benign breast tumors. Int $\mathrm{J}$ Cancer. 2000; 86: 204-07. https://doi.org/10.1002/(SICI)10970215(20000415)86:2<204::AID-IJC9>3.0.CO;2-6. [PubMed]

28. Malmström RE, Alexandersson A, Balmér KC, Weilitz J. In vivo characterization of the novel neuropeptide $\mathrm{Y}$ Y1 receptor antagonist H 409/22. J Cardiovasc Pharmacol. 2000; 36: 516-25. https://doi.org/10.1097/00005344200010000-00016. [PubMed]

29. Sampaio FA, Martins LM, Dourado CS, Revoredo CM, Costa-Silva DR, Oliveira VA, Alves-Ribeiro FA, Silva BB. A case-control study of Metallothionein-1 expression in breast cancer and breast fibroadenoma. Sci Rep. 2019; 9: 7407. http://doi.org/10.1038/s41598-019-43565-0. [PubMed]

30. van Slooten HJ, Clahsen PC, van Dierendonck JH, Duval C, Pallud C, Mandard AM, Delobelle-Deroide A, van de Velde CJ, van de Vijver MJ. Expression of Bcl-2 in node-negative breast cancer is associated with various prognostic factors, but does not predict response to one course of perioperative chemotherapy. Br J Cancer. 1996; 74: 78-85. https://doi. org/10.1038/bjc.1996.319. [PubMed]

31. Conover W. J. Nonparametrics statistics. $3^{\text {rd }}$ edition. Wiley, 1999.

32. Agresti A. Categorical Data Analysis. Wiley. 2013. 